\title{
THE SACRED, THE PROFANE AND TOURISM: EXPLORING INDICATORS OF SUSTAINABLE TOURISM DEVELOPMENT IN PARANGTRITIS AND PARANGKUSUMO, YOGYAKARTA ${ }^{1}$
}

\author{
Popi Irawan. \\ Universitas Gadjah Mada \\ popi.irawan@ugm.ac.id
}

\begin{abstract}
This research aims primarily at finding and assessing indicators of sustainable tourism (ST) that can be applied to assess Parangtritis and Parangkusumo beaches in Bantul Regency, Yogyakarta, as well as studying predominant indicators in supporting the sustainability of tourism activities in the area. Those indicators assessed and revealed in this research are partly based on set of ST indicators as outlined by the World Tourism Organization guidebook (2004). They have been chosen in respect to the concept of sustainable development, which covers three main areas: ecosystem or environment sustainability, social development and economic development, with the emphasis on socio-cultural indicators. In this research, indicators of sustainable tourism development that have been classified based on the concept of sustainable development are then assessed and studied to reveal possible and appropriate application in the area. In addition, some other indicators are also profoundly important in contributing to tourism sustainability in the area.
\end{abstract}

Keywords: indicators, sustainable tourism, socio-cultural, economic, coastal tourism

\section{Introduction}

Tourism in a region is commonly influenced by a number of factors, and is a complex phenomenon and susceptible to various influences. It is very complex in the sense that tourism is a multidimensional phenomenon (Cooper et al, 1998). It will be very easily affected, for example, by an interruption in safety and comfort.

Yogyakarta, a provincial-level region predicated as a special region, has long been known as one of the major tourist destinations in Indonesia. Located in the southern part of Java Island, Yogyakarta has been known nationally and locally as a tourist destination. It is popular among travelers, and statistic shows that in 2012 the province was visited by more than two million domestic tourists and some 200,000 foreign ones, staying in 12,420 hotel rooms (Dinas Pariwisata Daerah Istimewa Yogyakarta, 2013) . Besides its rich cultural heritage remnants

1 This article is part of a research report that has been published in Jurnal Kepariwisataan Indonesia Vol. 6 No. 3 by the same author as the first author. 
dating back to $9^{\text {th }}$ century, it is also the home of Mount Merapi, an active volcano located in the province's borders, which has been a natural attraction that draws domestic and foreign tourists for its unique volcanic environment.

In addition to cultural and historical attractions, Yogyakarta also offers coastal tourism. For this type of tourism, Parangtritis, which has been very popular in the eyes of tourists, especially domestic ones, is one of the most popular coastal tourism destinations in the province. Beaches along the southern part of Java Island, specifically Parangtritis, have long been tourism attraction that draw local but few foreign tourists. The location of this beach is approximately 40 kilometers south of the city center of Yogyakarta, or in the east part of the mouth of Opak River. Unlike other beaches in its vicinity, Parangtritis has long been developed as a tourist area.

However, Parangtritis as an integrated coastal tourism spot together with Parangkusumo and Depok, actually still has to be developed further, so that its existence as both coastal ecosystem and tourist zone will remain stable and sustainable. All this time, Parangtritis is developed with an emphasis on the unique features of its natural resources and the diverse tourist activities around the area. In addition, there are also tourism byproducts around Parangtritis area which become an integral part of the development. Though the area covers three beaches stretching from west to east, this study covers both Parangtritis and Parangkusumo beaches to represent two types of attractions: intended mainly for recreation (Parangtritis) and for cultural and spiritual purposes (Parangkusumo).

As a developed tourist area, both Parangtritis and Parangkusumo need to be more developed on the emphasis on the welfare of people living in and surround the area. The application of the concept of sustainable tourism development is considered one of the most reasonable and better choices. This is mainly carried out in order to maintain the quality of its attractions and natural environment and at the same time avoiding degradation or destruction that will result in the withdrawal of tourism sector in that area. Therefore, efforts to implement sustainable tourism development in the region is of primary important. To begin with, a systematic study on the sustainable tourism indicators is necessary in order to assess the extent to which Parangtritis can be considered sustainable.

This research is primarily aimed at revealing indicators of sustainable tourism (ST) in the area of Parangtritis and Parangkusumo coastal tourism destinations, the area that are close to each other and in fact a part of Yogyakarta southern coastal area. Those indicators are used to be applied to further assess the sustainability of the destination. Further, it explores the predominant ST indicators that distinguish it from other similar destinations. The set of ST indicators is mainly based on those outlined by the UNWTO, published mainly for managers and decision makers as part of destination management (WTO, 2004).

\section{Literature Review}

McIntyre (1993) and Inskeep, et al. (1993) suggests that sustainable development is a process that necessitates the implementation of development without causing degradation of resources that enable the development to occur through. This can generally be accomplished either by managing the resources so that they can renew themselves equivalent to the level of their use or by changing 
the level of the resource use whose rate of recoverability runs slow towards resources whose rate of recoverability runs faster. In this case, the existing resources are expected to support the present and future generations.

Sustainable tourism (ST) development can be regarded as a new course in tourism development considering that this concept emphasizes on sustainability and continuity, not only economy but also environment. Brutland Commission Report (Cater, 1994) suggests that sustainable development is "development which meets the needs of the present without compromising the ability of future generations to meet their own needs."

As a widely recognized tool for economic development, tourism has contributed considerably to the development of the economy of many countries on the planet. Hence, it tends to bring undesirable impacts in some areas, resulting, for instance, in the degradation on environment and socio-cultural lives of local people (Cooper et al, 1998). At least in the last two decades, sustainable tourism (ST) has been recognized and taken into account for the key principle in developing better tourism (Anna \& Palomeque, 2012). Though some experts had confronted sustainable tourism as being a principle and merely a product label (Mowforth, 1992) (Cater \& Lowman, 1994) as in the case of Sustainable Tourism Certification (Jarvis, Weedan, \& Simcoc, 2010), it is empirically practiced and realized in such action as community-based ecotourism (Jones, 2005).

Sustainable tourism development traditionally implies three dimensions: economic, social, and environmental dimensions (Swarbrooke, 2004). However, it is considered difficult in practice, particularly in finding balance within these three elements without institutional dimension (Cottrell, Vaske, \& Roemer, 2013). Environmental dimension has particularly drawn interests from large number of researchers, and has rapidly grown in spite of its infancy (Myung, McClaren, \& $\mathrm{Li}, 2012$ ). Despite its popularity in recent decades, the concept of sustainable tourism has also raised criticism particularly on its wide scale of applications, ranging from environmental, social, cultural, economic, to political issues in destinations and system. This has resulted in the need for more environmental and local people-friendly approaches in development, policies, and planning (Saarinen, 2006). Meanwhile, in a more general and conceptual study on social capital the concept of social capital is placed in a broader context of social dimension of sustainable tourism development (Mauerhofer, 2013). He argues that within the social dimension of tourism sustainability lie three important subsections of social aspect, namely social capital, social capacity, and social carrying capacity.

Developing a coastal area could be by a number of approaches, where tourism is only one of them. Another approach is known as integrated coastal management approach that is proved to be an effective tool for the government, particularly the local government where the coastal area is located, to promote overall sustainability in coastal governance, ecological environment and socioeconomic development in the coastal cities (Ye et al, 2015). Further to this approach, Chen \& Bau (2016) suggest a multi-criteria evaluation structure for assessing beaches as tourist destination. In this view, factors related to beach cleanliness and safety in doing activities in the coastal regions are perceived highest compared to other factors such as information provision and management actions. 
Beach is commonly a natural attraction for tourism, but few of them are sacred place as well. The notion of sacred place is very closely related with people beliefs and practices. However, the study or literature of sacred places and tourism in particular is rarely found (Andriotis, 2009). In the tourism context, studying sacred places is in fact exploring visitor's experience, and not necessarily the site per se. In this view, sacred place is seen as a place that give different experience for its visitors. In a study of Anthonite shrine of Sacred Mount of Athos in Greece, Andriotis (2009) found that visitor's experience was overwhelmed by its spirituality, and inspired by the features of its cultural element of architecture, heritage, ritual and the Byzantine monastic life.

Though the study on visitor's experience in sacred sites dominates the literature, it is argued that its pure religious purposes have been gradually replaced by profane intentions, to a more secular experience as in a study on one of the most celebrated sacred destination, the Cameo de Santiago of Spain, the route of thousands of pilgrims (Kim, Kim \& King, 2016). Other purposes are also not related directly with faith and religion but with a more psychological fulfillment such as social bonds, cross-cultural understanding, heathy life and better quality of life. The sacred sites are then perceived not only as places associated with spiritual wellbeing, but also places where visitors can gain better social and cultural understanding while at the same time fulfilling their psychological needs.

In relation with the study of ST indicators in a coastal tourist destination, indicators are determined in a certain way, i.e. by considering the concept of sustainable development. This is mainly carried out by considering that the concept of ST development is derived from the concept of sustainable development. This concept has a fairly broad meaning and has become the main basis of various concepts, policy and program development, including the development of tourism (Baiquni, 2007). Burger (cited by Baiquni, 2007) illustrates that the concept of sustainable development includes three main aspects, i.e. ecosystem sustainability, social development and economic development. These three aspects are interrelated with each other. In this study, the examined indicators are mainly referred from a guide book published by the World Tourism Organization (WTO, 2004) which includes three major groups, i.e. economic, social and environmental indicators.

Indicator is a measure of existence on current issues, a marker of situations and problems that will occur, a measure of risks and potential, as well as a tool used to identify and quantify the results that have been achieved (WTO, 204). Indicator is also a set of information that is filtered and used to measure changes in the context of tourism development and management. These indicators are used to measure: a) changes in the internal structure of tourism; b) changes in external factors that affect tourism; and c) impacts caused by the development of tourism (WTO, 2004). In addition to ST indicators outlined buy WTO, other methods are also available such as composite indicators utilizing combined principal component analysis (PCA) and data envelopment analysis (DEA) (Perez, et al, 2013). But in relation with the purpose of this study, indicators as outlined by the WTO are then used to be assessed in order to reveal the sustainability of tourism in Parangtritis and Parangkusumo areas.

\section{Methodology}

Journal of Business on Hospitality and Tourism 
In this study the data are primarily obtained by involving closely with stakeholders directly involved in tourism activities in both Parangtritis and Parangkusumo beaches. Those stakeholders could be described as: visitors themselves, local people, local authorities and those who involve in tourismrelated business. This research also make use of quantitative techniques in order to satisfy the research objectives, and to assess the indicators. Structured questionnaire is applied in order to reveal respondent's perception towards sets of indicators while at the same time, series of interviews are also conducted to selected informants. The selection of samples are determined based on purpose and is not chosen randomly with the total number of 100 respondents.

In practice, participant observations and interviews are used as the main techniques for obtaining primary data. In the interview, key informants are selected based on certain criteria. In the observation, In the case of interview technique, the informants fall into categories, namely visitors to the destination, local residents, people involved in tourism-related business in the destination (amenities owners, their staff), and local authorities. The consideration for selecting key informants is based on several criteria (Neuman, 2000) namely: a) they should be totally familiar not only with their culture but also with tourism and its wide range of activities; $b$ ) for the local people, they should be living in the areas of research, and directly or indirectly engage in activities related to tourism; and c) for other stakeholders, they should be totally or in part involve in tourism activities based on their roles in their organizations or businesses.

\section{Assessment of Indicators of Sustainable Tourism in Parangtritis and Parangkusumo}

a. ST's Economic Indicators

The study results revealed that the majority of respondents $(86 \%)$ enjoyed their visit in Parangtritis beach, which suggests that at a particular level visitors were satisfied and quite impressed with the tourism activities in Parangtritis. When the level of tourist satisfaction on a tourism attraction can be maintained, it is expected that they would make repeat visits. The results also showed that tourism activities in the Parangtritis left nice memories, and this contributed greatly to maintaining the sustainability of tourist objects and contributed highly to the economic condition in that area.

Further, the research data are also supported by other results that support the level of tourist satisfaction of objects studied. The things that support them include: easy access to destination (51\%), fairly easy access to cultural heritage sites $(40 \%)$, relatively cheap price (52\%), and beautiful landscape (78\%). Another indicator is that relating to the impact of tourists' satisfaction which is expressed by their willingness to make a repeat visit. This study results indicated that the percentage of tourists expressing their desire to make a repeat visit was quite high, reaching up to $59 \%$.

In addition, Parangtritis also experiences two peak seasons which generally occur in June-July and in the end of the year, around NovemberDecember. The peak season in June-July occurs because these months coincide with school holidays in Indonesia, where most of the visitor come from. In fact, therefore, visitors to Parangtritis in such a season are mainly elementary to high school students. Meanwhile, in November-December, the peak season is more 
triggered by holiday festivals (such as Islamic festivity of Eid al-Fitr and Christmas) and new year celebrations as well.

Table 1

Number of Visitors to Parangtritis ${ }^{2}$

\begin{tabular}{l|ll} 
Year & Number of Visit & Percentage \\
\hline 2007 & 949,621 & - \\
2008 & $1,196,771$ & $26 \%$ \\
2009 & $1,323,857$ & $10.6 \%$ \\
2010 & $1,174,872$ & $-11.3 \%$ \\
2011 & $2,072,085$ & $76.4 \%$ \\
2012 & $1,773,179$ & $-14.4 \%$ \\
2013 & $1,574,730$ & $-11.2 \%$
\end{tabular}

Source: Dinas Pariwisata Daerah Istimewa Yogyakarta, 2013

The above table reveals that number of visitors to Parangtritis is fluctuating, though it is almost always reaching above one million visitors each year after 2007. For the regency of Bantul where Parangtritis is located, this number is one of the highest contribution to overall visitors to the regency. In Yogyakarta, in general, the emerging coastal tourism destinations are located in the regency of Gunung Kidul, which once were substantially lower in number of tourist visits compared with that of Bantul (Dinas Pariwisata Daerah Istimewa Yogyakarta, 2013).

In terms of employment opportunities, this study suggests that people in Mancingan village, the location of Parangtritis and Parangkusumo, are generally engaged in the tourism business, either by running their own businesses or being employed in the tourism sector. Respondents, including the head of Mancingan village, reveals that nearly 90 percent of Mancingan inhabinants are involved in tourism activities through which almost all of them were self-employed. This number is significant that the majority of people involve, directly or indirectly, in tourism which means that it contributes a lot to the economy of the local people.

Mancingan village was originally occupied by only a small group of people working mainly as farmers. But due to the tourism development in Parangtritis area, Mancingan village is now inhabited by a great number of outsiders coming to work in the tourism sector. Indeed, the agricultural sector still remains running as evidenced by the presence of the cultivation of lands around the village. Nevertheless, the farmers or farm workers also sometimes change their profession to be employees or run various businesses in the tourism sector around Parangtritis particularly during the peak season. Currently, the majority of Mancingan people are working in the tourism service sector around Parangtritis. Similar thing also happens to Parangkusumo as this beach is located on the same village. As seen from Table 2 below, it appears that the percentage of

\footnotetext{
${ }^{2}$ The data presented here is number of visitors to the area of Parangtritis which covers two beaches located in the same coastal line. They are Parangtritis and Parangkusumo respectively. Local authorities measures number of visitors by counting those who pass one retribution gate to the destination.
} 
local community who runs business in the tourism sector for livelihood is very high $(86.4 \%)$ as compared to other professions.

Table 2

Types of Community's Livelihood in Mancingan Village

\begin{tabular}{|c|c|c|c|}
\hline No. & Livelihood & Number & Percentage \\
\hline 1 & $\begin{array}{l}\text { Civil servants, government } \\
\text { employees }\end{array}$ & 71 & 0.05 \\
\hline 3 & Farmers & 45 & 0.03 \\
\hline 4 & Employees/Labors & 42 & 0.03 \\
\hline 7 & Businessmen/vendors & 1,144 & 86.4 \\
\hline \multirow[t]{2}{*}{8} & Pensioners & 12 & 0,009 \\
\hline & TOTAL & 1324 & \\
\hline
\end{tabular}

Source: adapted from the Monograph of Mancingan Village, Parangtritis, 2009.

The fact that local people are exposed to opportunities provided by tourism sector is one of the indicators of ST development in a destination. The very significant number of local people who work or run their business in tourism (almost 90\%) is evidence of this indicator. In fact, an established destination like Parangtritis has also attracted not only visitor or tourists but also other people who wish to work or earn their income from tourism-related businesses around the destination. This further suggest that economically, Parangtritis and Parangkusumo area are not only viable for their local people but also for people from neighboring villages.

This research finds that economically Parangtritis and Parangkusumo destinations contribute to the development of local people economy by providing significant number of job opportunities not only for local people but also for people from neighboring villages. At the same time, people original occupationmainly as farmers-are still their main job. The number of opportunities in tourism sector is significant compared to other livelihood and to the total number of villagers of Mancingan, where the destinations re situated. The following table summarizes issues and their indicators related to economy:

\section{Table 3 \\ ST Issue and Its Indicators (Economic)}

\begin{tabular}{l|ll} 
Component of the issues & Indicators & Evidence \\
\hline $\begin{array}{l}\text { Number and quality of } \\
\text { employment in the tourism } \\
\text { sector }\end{array}$ & $\begin{array}{l}\text { Total number } 1,144 \text { compared to the } \\
\text { employed in the total number of residents } \\
\text { tourism sector } \\
\text { Retention level of High } \\
\text { employees } \\
\text { Percentage of jobs that Average } \\
\text { are full time, full year } \\
\text { Local unemployment Low } \\
\text { rate in low season }\end{array}$
\end{tabular}




\begin{tabular}{l|ll}
$\begin{array}{l}\text { Professional and personal } \\
\text { development }\end{array}$ & $\begin{array}{l}\text { Number of employees Low } \\
\text { qualified/certified } \\
\text { Training funds spent Low } \\
\text { per employee }\end{array}$ &
\end{tabular}

Source: WTO, 2004, modified

The above table show that it is only the total number of employment that is substantially high, and other indicators are low (except for percentage of full time job). However, the fact that other indicators are low does not support the argument that economically tourism in Parangtritis and Parangkusumo does not contributed to the welfare of the people since job opportunities available in the destinations does not require special, trained skills. Most jobs are those related to low skilled opportunities, and not those that require special qualification or certification. Even accommodation facilities in the destination are categorized as non-classified hotels. In fact, local people, who are mostly farmers, work in tourism-related business not as their only occupation. Many of them retains their occupation as farmers. Therefore, local unemployment, numbers of certified employees and training fund spent for employee are low. WTO indicators, in this research findings, could not be strictly applied without considering the culture and how local people perceive what an occupation is. The same is true with income, which is differently perceived from a community with another. It is possible that the income earned by local people working in tourism sector is perceive low in a community. But this study suggests that this fact could not be generalized. This study reveals that overall, the local community are satisfied with tourism in their region.

\section{b. ST's Socio-Cultural Indicators}

In Parangtritis Tourism Area, which includes Parangkusumo, the level of local community satisfaction of tourism was generally quite good. The growing tourism sector has created significant work opportunities. Interviews with local authorities, reveals that almost 90 percent of community living in the village, which is the location where Parangtritis and Parangkusumo tourist destinations, is working in tourism business services sector. The Monograph Data of Mancingan Hamlet, Parangtritis Village, in 2009 showed that out of 1,332 working-age people, as many as 1,129 of them were working in the tourism services sector.

Furthermore, the interview respondents revealed that the level of population satisfaction could be maintained since they perceived, as a native community, their lives and tourism activities needed each other. When the local government managed their area, in general, actually the local people did not show resistance. Instead, as claimed by the head of environmental affairs at Parangtritis Village, the villagers wished the tourism activities in their area to be organized for they felt that with an arrangement then their chances of engaging in tourism activities would be fairer.

However, the interviews with several community leaders revealed that there was indeed still community's resistance to tourism. The dissatisfaction and disapproval of community actually arose as a result of the negative impacts of tourism. The local authority claimed that, so far, there was no official complaint 
and/or protest from people rejecting the tourism activities. In this case, the government officials and local leaders have employed personal approach.

Tourism activities in an area will bring significant impacts to the surrounding community. This impact can be both positive and negative. Both impacts, when managed well and appropriately, may contribute to the sustainability for a tourist area. The positive impact of tourism is primarily on the economic sector. Undeniably, tourism activity in an area will lead to significant multiplier effect in the economic sector.

In terms of socio-cultural indicators found in Parangtiris and Parangkusumo areas, it is in Parangkusumo area that the cultural implications are found imminent than in Parangtritis. This is because Parangtritis is intended almost exclusively for recreation, while Parangkusumo is culturally a sacred site, especially for Javanese people. This is the site in which Javanese believe to be the place where the founder of ancient Javanese Empire of Mataram met the so-called 'ruler of the Southern Sea', which is the most important mythological character for most Javanese. Besides, the palace also holds an annual ritual, a ceremony, in this beach which is called the 'labuhan', a ceremony where people carry offerings for the spirit.

In Parangtritis and Parangkusumo, the surrounding communities perceived the direct impacts of tourism, both positive and the negative. As outlined above, the people enjoyed the positive impacts of tourism activities in terms of increasing income earnings. Initially, the majority of people in the surrounding area only had relied on agricultural sector. But now, they could expand their source of livelihood in the sector of tourism services as souvenirs traders, food vendors, clean water providers, tourist carriage drivers, and many others. On the other hand, they also worried about the undesirable effects such as increased level of prostitution, especially around Parangkusumo Beach.

This study suggests that tourism in Parangtritis and Parangkusumo is notably different, where that of Parangtritis is for coastal recreational activities while that in Parangkusumo is mainly for rituals. Though the coastal landscape and the type of beach is similar, but visitors can see notable differences of the atmosphere in these two neighboring beaches. It is common to see people sitting in contemplation on the beach, carrying some kinds of offerings that they believe as means of communication with the spirit.

Further, it is also revealed that in terms of ST indicators found in the location of sacred site of Parangkusumo, the profound thing is not on how local community reacts to impacts of tourism in the area. They, at the same time, perceive that the site should be protected as it is the official property of the palace or the Sultanate of Yogyakarta. The sultan even built this area and improved its facilities such as park and several small buildings to house ritual equipment. The most sacred site, which is a black sharp stone, is put in a place surrounded by walls and is guarded by an official personnel of the palace called 'juru kunci' ${ }^{4}$. Therefore, local community perceive that they are part of the sacred site, and they also own and protect it. Economically, local people also earns money by selling local products in their stalls as in neighboring beach of Parangtritis.

\footnotetext{
${ }^{3}$ Traditionally, this mythological character is named Nyai Roro Kidul, which is believed to be the 'wife' of every Mataram king or sultan. This belief exists to present day.

${ }^{4}$ Literally means 'someone who holds the key'.
} 
In addition, the seasonality of both Parangtritis and Parangkusumo is also different in that the peak season in Parangtritis occurs during the holiday time around June to July, and end of year, while that of Parangkusumo occurs during the first month of Javanese calendar ${ }^{5}$. This happens as the most important rituals and ceremonies are held during this time. Besides, the peak season of the visit is not during the day, but during the night especially on the Javanese New Year's Eve, where people gathered in the sacred site, praying and contemplating. Visits during the day are also common, but the Javanese believe that the best time to visit this site is on the time where rituals and ceremonies are held.

From the view of ST development, it is important to note that local community is an integral part of the site in the case of Parangkusumo. They take their part not only to participate in economic activities but as an important stakeholder to the site. The ST indicators outlined by the WTO (2004) are somewhat irrelevant to some extent to be applied to a destination like Parangkusumo. Culturally, local community are bound to the sacred place in their village, and traditionally they pass mythologies (or information) from generation to generation. The ST indicators of community involvement and awareness (WTO, 2004 pp 83 - 84) do not exist if the WTO standards are strictly applied. However, culturally these awareness and involvement are inherent in people's everyday lives as they had been parts of their belief and culture. Below is set of ST indicators related community involvement and awareness:

Table 4

\section{ST Issue and Its Indicators (Socio-cultural: local people involvement and awareness)}

\begin{tabular}{|c|c|c|}
\hline Component of the issues & Indicators & Facts \\
\hline \multirow[t]{3}{*}{ Availability of information } & $\begin{array}{l}\text { Number and types of } \\
\text { channels used to promote } \\
\text { ST }\end{array}$ & $\begin{array}{l}\text { Information is } \\
\text { inherent in the lives } \\
\text { of local people; } \\
\text { channels are } \\
\text { 'traditional' trough } \\
\text { regular meeting and } \\
\text { cultural events }\end{array}$ \\
\hline & $\begin{array}{l}\text { Number of people accessing } \\
\text { information }\end{array}$ & $\begin{array}{l}\text { Local people } \\
\text { themselves 'own' } \\
\text { the information }\end{array}$ \\
\hline & $\begin{array}{l}\text { Frequency of access (per } \\
\text { person) }\end{array}$ & $\begin{array}{l}\text { Local people } \\
\text { themselves 'own' } \\
\text { the information }\end{array}$ \\
\hline Analysis of information & $\begin{array}{l}\% \text { of people that have clear } \\
\text { understanding of the role of } \\
\text { ST planning }\end{array}$ & $\begin{array}{l}\text { Low; local people } \\
\text { rely almost solely on } \\
\text { their trust to the } \\
\text { Sultanate that owns } \\
\text { the site }\end{array}$ \\
\hline
\end{tabular}

\footnotetext{
${ }^{5}$ Unlike the Gregorian, the Javanese calendar is a lunar calendar adapted from both Hindu and Islamic calendars. Important Javanese rituals and ceremonies are based on this system. The first month of the Javanese calendar system is called Sura.
} 
Application of information

Advocacy of information

\begin{tabular}{|c|c|}
\hline $\begin{array}{l}\text { Number of time information } \\
\text { on ST is used within the } \\
\text { broader community context }\end{array}$ & Low \\
\hline $\begin{array}{l}\text { Number of agencies } \\
\text { applying information on } \\
\text { sustainability aspects to their } \\
\text { strategic planning process }\end{array}$ & Low \\
\hline $\begin{array}{l}\text { Degree to which the } \\
\text { community is satisfied with } \\
\text { the quality and quantity of } \\
\text { information on tourism } \\
\text { issues and sustainability }\end{array}$ & $\begin{array}{l}\text { Local people } \\
\text { themselves 'own' } \\
\text { the information }\end{array}$ \\
\hline $\begin{array}{l}\% \text { of visitors receiving } \\
\text { information on ST practices } \\
\text { provided prior to their visit } \\
\text { to the destination and at the } \\
\text { destination }\end{array}$ & $\begin{array}{l}\text { Visitors to the } \\
\text { sacred site of } \\
\text { Parangkusumo are } \\
\text { by themselves } \\
\text { informed to respect } \\
\text { every single thing at } \\
\text { the destination }\end{array}$ \\
\hline
\end{tabular}

Number of time information on ST is used within the broader community context Number of agencies sustainability aspects to their strategic planning process Degree to which the community is satisfied with the quality and quantity of information on tourism issues and sustainability $\%$ of visitors receiving information on ST practices to the destination and at the destination

Source: WTO, 2004, modified.

Table 4 above suggests that not only should ST indicators outlined by the WTO be modified but also the facts found in the field do not necessarily support the indicators. However, this does not mean that sustainable tourism is absence at the destination. This research further suggests that in terms of local people involvement and awareness indicators set by the WTO are not entirely confirmed since their application disregards culture and values unique in every region.

Further, the issue of conserving heritage as one of the issues in assessing ST indicators is also an important point suggested by this research. The fact that the site is a heritage suggests that it should be protected. Although is not a UNESCO's world heritage, its values are of prime importance for local community in particular and for the Javanese people in general. However, assessing indicators related to heritage protection by local people could not particularly use the WTO's ST indicators as they perceive the site as part of their culture and environment. It is the government, local and national, that are responsible to legally and officially protect the site by establishing policies, laws, and allocating funds. In the case of Parangkusumo, there are three parties that are responsible for protecting the site. They are the government, the Sultanate, and local community. It is therefore much suitable to assess the indicators by exploring local culture and values rather than by suggested list from an institution like the WTO. Its set of indicators cold not always be applied in different culture and environment.

In addition to positive and negative impacts of tourism on local community, this study also explored the existence of the community's tourism planning. As it is known, in Indonesia, a planning authority especially of the tourist area is held by the policy holder, in this case the local government. In case of Parangtritis tourism objects, some management has been done, such as, on souvenir and food stalls along Parangtritis Beach and Parangkusumo Beach, and a 
road linking both beaches has also been already built. According to the interview respondents, the planning of tourism area management was almost entirely performed by the local government, even though people in the surrounding area were also invited to contribute our thoughts (deliberation), capturing people's aspiration. Once more, neglecting local people could result in conflicting policies.

In the observed destinations, the number and capacity of social services available were sufficient. But in some other places, they were less representative. Indirectly, the local people maight also make benefit from these social services. Some social service facilities include, for example, worship facilities and health centers whose existence was quite representative but some were still considered less representative.

According to one of the interview respondents in Mancingan village, some social services in the Parangtritis and Parangkusumo tourism objects were not representative. For example, the places of worship like mosque and prayer rooms (mushala) ${ }^{6}$ were regarded not as representative as those in other tourist objects such as Samas Beach, Baron Beach, and Depok Beach. The mosques and prayer rooms (mushala) in Parangtritis and Parangkusumo tourist objects were relatively small, whereas the number of visitors to both beaches was averagely high. On the whole area of Mancingan village itself there were only 2 mosques and 5 broken mushalas.

In the observed area, it is undeniable that tourism development has had an impact on the cultural life of the local community. According to the interview respondents in Mancingan village, actually there was no prominent serious impact of tourism on the local culture. Indeed, tourism has more or less influence on the local culture, but according to the interview respondents, the contents and standard rules of local culture remained unchanged.

However, tourism development brought impacts on the togetherness (mutual cooperation) of communities around Parangtritis area. According to the interview respondents, since the tourism activities in Parangtritis tourism object was developed, the community's mutual cooperation has been fairly faded. It was much more caused by area management which, according to some elements of community, was less fair. This then resulted in the lower values of mutual cooperation in the community of Mancingan Hamlet, Parangtitis Village.

On the other hand, the analysis results of questionnaires showed that in general $(52 \%)$ tourists felt safe when they visited the Parangtritis area. The low crime rate led tourists to feel secure in doing their activities. Although the volume of vehicles parked in the parking area was very high the when peak season, there was no report of motor vehicle theft so that they felt safe to park their vehicles in several parking area scattered around tourism object.

However, it should be noted that there is one other factor to consider, i.e. the security of the tourists doing activities on the shoreline since the waves along the beach in the Parangtritis Tourism Area is quite high. The level of security in tourist activity on the shoreline could be said low. Lots of tourists did not heed the ban for not bathing on the beach despite the ban and warning boards from the Search and Rescue team.

\footnotetext{
${ }^{6}$ Since the destination is more popular among domestic visitors, the provision of Muslim's prayer room (mushala) is important. Mushalas are common in tourist spots in Java and other island where Muslim visitors dominate the visits.
} 


\section{b. ST's Environmental Indicators}

In both Parangtritis and Parangkusumo areas, it can be seen that the management has already done, especially in a complex of Parangtritis. In the eastern part of beach, the complex for souvenirs and food stalls has also been built. Meanwhile, a road has been built to connect Parangtritis-Parangkusumo Beach with Depok Beach, another nearby beach for recreation. Around the Parangtritis complex, several facilities have also been built including food stalls, souvenir shops, open-air stage, performance stage, and parking area. Meanwhile, lodgings, inns and hotels were generally built on the roadside north of the beach.

With this management, it is expected that the cleanliness and beauty of Parangtritis and Parangkusumo can be maintained. But in reality, there were still plenty of food vendors that operated exactly on the edge of the beach. They did not utilize the complex of food stalls and souvenirs at New Parangtritis Complex or on the north road which was specifically provided to them. This, of course, made the beach seedy with piles of garbage from the stalls at this shoreline.

On the other hand, the food vendors actually had to occupy the area north of the road, rather than that on the shoreline. Nevertheless, some still occupied an area on the shoreline. Consequently, the resulting wastes were piled up on the shoreline, thereby polluting and damaging the beauty of the beach. This definitely affected the comfort of tourists who did activities on the beach. Such a condition was not much different from Depok Beach. Many food stalls along the beach which were located very close to the shoreline were still not able to manage their wastes well. This made piles of wastes like coconut husks apparent on the shoreline.

Procedurally, the waste management in Parangtritis area is performed by collecting waste from households and food stalls and then discharging them into the Final Disposal. But in reality, vendors who sold on the shoreline did not follow this procedure. As a result, a huge amount of garbage was piled up in the sand dunes around the beach, ditches north of beach, and even on the shoreline itself.

In addition to the management of wastes (solid and liquid), and the existence and condition of groundwater also play an important role. Fresh groundwater in this area was quite easy to obtain, generally from the dug wells. The amount of groundwater was relatively abundant. This could be seen from the large number of public bathrooms lining up along Parangtritis beach. Moreover, there was a kind of swimming pool made of tarpaulin which also used the ground water. If averaged, the groundwater consumption by tourism sector was quite high. However, the need for fresh water could still be met.

On the other hand, the quantity of fresh groundwater should be balanced with good quality of water (feasible for consumption). Seeing the rapid development of tourism without good waste management, the quality of groundwater might also be affected. In general, the tourism industry actors such as shop owners, street vendors, and hotel and inn owners were still not aware of the importance of waste management and the making of a good place for waste water. In addition, this area also did not have drainage channel mains so that the waste from bathrooms and toilets which were scattered along the Parangtritis Beach and Parangkusumo Beach were just let out to absorb into the soil. Around 
the core area of tourism, there was also no solid waste temporary disposal. This made the quality of groundwater less good.

In relation to the level of beach cleanliness, the quality of the sea water around the destination should also be taken into account. This was due to the importance of the quality of sea water (clean and not contaminated by waste) for tourists who did a lot of activities on the beach. The sea water quality data indicated that, in general, some aspects of the quality of sea water in Parangtritis beach exceeded the quality standard. This means that the specification of the amount of pollutants that may be discharged or the amount of contents that may be contained in an ambient medium exceeds the limit predetermined by the government.

\section{Conclusions}

There are some very important factors in maintaining the sustainability of tourism development. These include economic, socio-cultural and environmental aspects which are interconnected with each other in achieving a sustainable tourism development. The indicators of economic advantages for the surrounding community play a very important role. Based on the study results, since the beginning of the development of Parangtritis and Parangkusumo beaches, there has been an increased diversification of income sources as a result of the development of the tourist area. This is evidenced by the wide employment opportunity in the tourism sector for the local community. Another important aspect in the development of tourism in an area is the local community satisfaction of tourism activities since the tourism sector, especially, has brought economic and social benefits in the forms of diversification of income sources and increased quantity and quality of infrastructure which are indirectly felt by surrounding communities.

This study suggests that applying ST indicators to assess the sustainability of observed destination using sets of indicators outlined by the WTO can be done partly but not the whole indicators are found or proven through this research. Instead, those indicators could be modified according to local culture, norm, and values. This study once more suggests that though the set of ST indicators have been outlined and suggested, they have limitations when applied in a destination, especially when local values and cultures are not part of consideration. This study, therefore, possesses a limitation in that it does not further explore what methods that could be used to reveal the ST indicators for a destination like Parangtritis and Parangkusumo, two similar coastal destination but distinct in its values.

\section{REFERENCES}

Anna, T.-D., \& Palomeque, F. L. (2012). The Growth and Spread of the Concept of Sustainable Tourism: The Contribution of Institutional Initaitives to Tourism Policy. Tourism Management Perspectives, 4, 1-10.

Andriotis, Konstantinos. (2009). Scred Site Experience A Phenomenological Study. Annals of Tourism Research Vol. 36 No. 1 pp. $64-84$. 
Chen, Chung-Ling \& Bau, Yi-Ping. (2016). Establishing a Multi-criteria Evaluation Structure for Tourist Beaches in Taiwan: a Foundation for Sustainable Beach Tourism. Ocean \& Coastal Management. (121). pp 88-96

Baiquni, M. 2007. Strategi Penghidupan di Masa Krisis Belajar dari Desa. Yogyakarta: IdeAs Media.

Cater, Erlet \& Gwen Lowman Ed. (1994). Ecotourism A Sustainable Option? Chichester: John Wiley \& Sons.

Cottrell, S. P., Vaske, J. J., \& Roemer, J. R. (2013). Resident Satisfaction with Sustainable Tourism: The Case of Frankwald Natural Park, Germany. Tourism Management Perspective(8), 42-48.

Dinas Pariwisata Daerah Istimewa Yogyakarta. (2014). Statistik Kepariwisataan 2013. Yogyakarta: Dinas Pariwisata DIY.

Government of Parangtritis Village. (2010). Data Monografi Pedukuhan Mancingan Desa/Kelurahan Parangtritis Kecamatan Kretek Tahun 2009. Unpublished document

Gunn, Clare A. 1994. Tourism Planning: Basics, Concepts, Cases. USA: Taylor and Francis.

Inskeep, Edward. 1991. Tourism Planning an Integrated and Sustainable Development Approach. New York: Van Nostrand Reinhold.

Jarvis, N., Weedan, C., \& Simcoc, N. (2010). A Case Study of the Green Tourism Business Scheme in the West of England. Journal of Hospitality and Tourism Management, 7, 83-93

Jones, S. (2005). Community-Based Ecotourism The Significance of Social Capital. Annals of Tourism Research, 32(2), 303-324.

Kim, Bona., Kim, Seongseop Sam \& King, Brian. (2016). The Sacred and the Profane: Identifying Pilgrim Traveler Value Orientations Using Means-end Theory. Tourism Management (56) pp 142 - 155.

Mauerhofer, V. (2013). Social Capital, Social Capacity and Social Carrying Capacity: Perspectives for the Social Basics within Environmental Sustainability. Futures(53), 63-73.

McIntyre, George. Arlene Hetherington and Edward Inskeep. 1993. Sustainable Tourism Development: Guide for Local Planners. Spain: WTO Publication.

Mowforth, M. (1992). Ecotourrism: Terminology and Definitions. University of Plymouth Research Report. 
Myung, E., McClaren, A., \& Li, L. (2012). Environmentally Related Research in Scholarly Hospitality Journal: Current Status and Future Opportunities. International Journal of Hospitality Management(31), 1264-1275.

Newman, W. Lawrence. (2000). Social Research Methods Qualitative and Quantitative Approaches. $4^{\text {th }}$ edition. Boston: Allyn \& Bacon.

Perez, Victor., Guerrero, Flor., Gonzalez, Mercedes., Perez, Fatima \& Cabalerro, Rafael. (2013). Composite Indicator for the Assessment of Sustainability: The Case of Cuban Nature-based Tourism Destinations. Ecological Indicators (29) pp. $316-324$.

Saarinen, J. (2006). Tradition of Sustainability in Tourism Studies. Annals of Tourism Research, 33(4), 1121-1140.

Swarbrooke, J. (2004). Sustainable Tourism Management. Wallingford: CABI Publishing.

World Tourism Organization. 2004. Indicators of Sustainable Tourism Development for Tourism Destination: A Guide Book. Madrid: WTO.

Ye, Guangqiong., Chou, Loke Ming., Yang, Shengyun., Wu, Jiaping., Liu, Pei \& Jin, Changwei. (2015). Is Integrated Coastal Management an Effective Framework for Promoting Coastal Sustainability in China's Coastal Cities? Marine Policy (56). pp 48 - 55. 